\title{
Detection of new potentially pathogenic mutations in two patients with primary pigmented nodular adrenocortical disease (PPNAD) - case reports with literature review
}

Wykrycie nowych, potencjalnie patogennych mutacji u dwóch pacjentów z pierwotną pigmentową chorobą guzkową nadnerczy (PPNAD) — opis przypadków wraz z przeglądem piśmiennictwa

\author{
Katarzyna Pasternak-Pietrzak', Constantine A. Stratakis ${ }^{2}$, Elżbieta Moszczyńska', \\ Agnieszka Lecka-Ambroziak', Michat Staniszewski ${ }^{1}$, Urszula Wątrobińska' ${ }^{1}$ Charalampos Lyssikatos ${ }^{2}$, \\ Monika Prokop-Piotrkowska ${ }^{1}$, Wiesława Grajkowska ${ }^{3}$, Maciej Pronicki ${ }^{3}$, Mieczysław Szalecki1, 4 \\ ${ }^{1}$ Department of Endocrinology and Diabetology, The Children's Memorial Health Institute (CMHI), Warsaw, Poland \\ ${ }^{2}$ Section on Genetics and Endocrinology, Eunice Kennedy Shriver National Institute of Child Health and Human Development \\ (NICHD), National Institutes of Health (NIH), Bethesda, MD, USA \\ ${ }^{3}$ Pathology Department, The Children's Memorial Health Institute, Warsaw, Poland \\ ${ }^{4}$ The Medicine and Health Sciences Faculty, University of Jan Kochanowski, Kielce, Poland
}

\begin{abstract}
Introduction: Primary pigmented nodular adrenocortical disease (PPNAD) is a rare form of ACTH-independent Cushing's syndrome (CS). Half of patients with PPNAD are sporadic cases and the other half familial.

Material and methods: We present two patients with PPNAD confirmed by genetic analysis.

Results: In both patients there were no abnormal findings on diagnostic imaging of both adrenals and heart. Patients underwent bilateral two-stage adrenalectomy. Histopathological examination confirmed PPNAD. Genetic testing showed the following mutations in the PRKAR1A gene coding for the regulatory subunit type 1A of the protein kinase A enzyme: c.125dupG (patient 1) and c.15dupT (patient 2). Both these defects lead to inactivation of the PRKAR1A protein and are consequently causative of PPNAD in these patients.

Conclusions: The novel mutations presented in this article are considered to be pathogenic for PPNAD. (Endokrynol Pol 2018; 69 (6): 675-681)

Key words: Cushing's syndrome; nodular adrenocortical disease; Carney complex; PPNAD
\end{abstract}

\section{Streszczenie}

Wstęp: Pierwotna pigmentowa choroba guzkowa nadnerczy (PPNAD) jest rzadką formą ACTH-niezależnego zespołu Cushinga (CS). W połowie przypadków PPNAD występuje w postaci sporadycznej, w pozostałej połowie rodzinnie.

Materiały i metody: Przedstawiono opis przypadków 2 pacjentów z PPNAD potwierdzonym badaniem genetycznym.

Wyniki: U obojga pacjentów nie znaleziono nieprawidłowości w badaniach obrazowych nadnerczy i serca. Chorzy przebyli obustronną etapową adrenalektomię. W badaniu histopatologicznym potwierdzono PPNAD. W badaniu genetycznym wykazano następujące mutacje w genie PRKAR1A kodującym jednostkę regulatorową typu 1A kinazy proteinowej A: c.125dupG (pacjent 1) i c.15dupT (pacjent 2). Oba te defekty prowadzą do inaktywacji białka PRKAR1A i w konsekwencji są przyczyną PPNAD u opisywanych pacjentów.

Wnioski: Nowe mutacje przedstawione w niniejszym artykule są rozważane jako patogenne w PPNAD. (Endokrynol Pol 2018; 69 (6): 675-681) Słowa kluczowe: zespół Cushinga; guzkowa choroba nadnerczy; zespół Carneya; PPNAD

\section{Introduction}

Primary pigmented nodular adrenocortical disease (PPNAD) is a rare form of ACTH-independent Cushing's syndrome (CS). Primary adrenal hypercortisolism is responsible for $10-20 \%$ of all cases of CS caused by adrenal adenomas (unilateral) and less often adrenal carcinomas (usually unilateral) and bilateral adrenal hyperplasia (BAHs) [1]. The latter is classified by the size of the nodules on high-resolution computed tomography (CT) to: smaller than $1 \mathrm{~cm}$ (micronodular hyperplasia) or larger than $1 \mathrm{~cm}$ (macronodular hyperplasia) and the presence or absence of pigmentation on pathological examination [2]. The most common forms of adrenal hyperplasia are: primary bilateral macronodular adrenal hyperplasia - PBMAH (also known as massive macronodular adrenal hyperplasia, MMAD) with nodules usually $>1$ $\mathrm{cm}$, PPNAD, and isolated micronodular adrenocortical disease (iMAD) with nodules $<1 \mathrm{~cm}$. PPNAD may be isolated or may occur as part of Carney complex (CNC) 
with co-existent heart and skin myxomas, lentigines of skin and mucosa, breast fibroadenomas, and other endocrine gland tumours [3]. Mutations of the PRKAR1A gene coding for the regulatory subunit type $1 \mathrm{~A}$ (R1A) of the protein kinase $\mathrm{A}(\mathrm{PKA})$ enzyme are responsible for the disease in most affected patients $[4,5]$.

\section{Material and methods}

In the article we characterize two patients with PPNAD, including the genetic testing.

\section{Results}

\section{Case report 1}

A 15-year-old Caucasian female patient was referred to the Endocrinology Department CMHI due to slow growth rate and excessive weight gain for about three years. She was the third child of healthy parents and was born full-term after an uneventful pregnancy. During early childhood there were no health problems, growth and development proceeded normally. At the age of eight years she had excision of a myxoma of the external auditory canal and several years later excision of a perineal myxoma.

On admission, typical features of hypercortisolism were found (central obesity, hirsutism, bruises, and petechiae), as well as scars after surgeries and melanosis of the anterior segment of the eye. Pubertal development was at Tanner stages: pubic hair 4 , breast 3, no menarche [6].

Laboratory tests showed (Table I and II): normal morning cortisol level, loss of a circadian cortisol rhythm, slight increase of plasma cortisol after low-dose ( $0.5 \mathrm{mg}$ every six hours for two days) and high-dose (2 mg every six hours for two days) dexamethasone suppression test (LDDST, HDDST-Liddle's test), and low plasma ACTH level (4.73 pg/ml; N: 10-60). The urinary steroid profile showed increased excretion of free cortisol and cortisol metabolites and no inhibition after both LDDST and HDDST, there was a slight increase of cortisol metabolites after HDDST. In the abdominal USG tumour of the right adrenal gland was suspected, and the left adrenal gland was enlarged. Repeated ultrasound examination and CT showed no abnormalities of adrenals. The echocardiogram was normal. Densitometry showed low bone mineral density (BMD) (total Z-score: -2,3 SD; L2-L4:-3,4 SD) [7, 8]. ACTH-independent $C S$ was diagnosed with suspicion of $\mathrm{CNC}$. The patient underwent right-sided laparoscopic adrenalectomy. Histopathological examination revealed typical PPNAD features (Fig. 1). Perioperative hydrocortisone (HC) therapy was performed, and HC was discontinued. Despite normal cortisol level, symptoms of adrenal

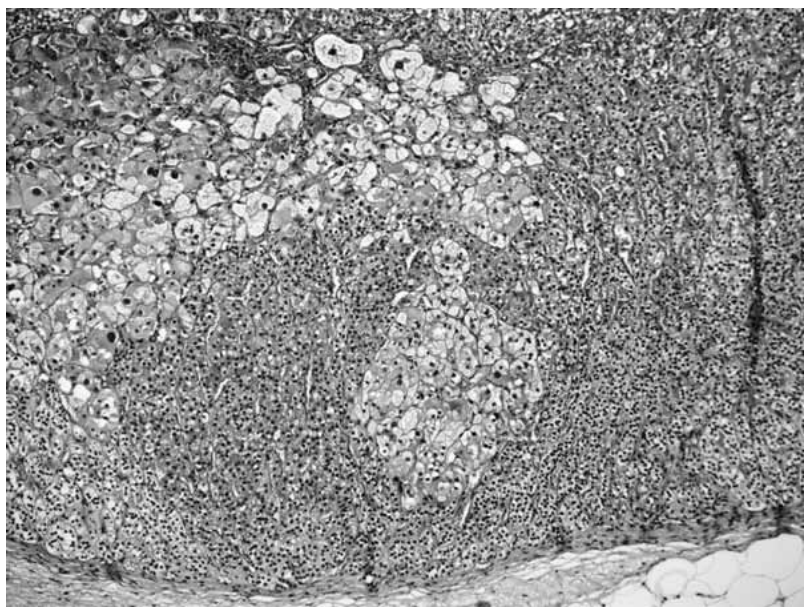

Figure 1. PPNAD, adrenal gland (patient 1). Original magnification $200 \times$, haematoxylin and eosin staining

Rycina 1. PPNAD, nadnercze (pacjent 1). Oryginalne powiększenie $200 \times$, barwienie hematoksylina i eozyna

insufficiency were observed (vomiting, hypotension) subsequently. The patient remained on substitutional HC therapy. Clinical improvement and gradual withdrawal of hypercortisolism symptoms were observed for six months, then she again developed symptoms of CS: weight gain $(4 \mathrm{~kg})$ and hirsutism. Laboratory tests revealed loss of a circadian cortisol rhythm (Table I). Left-sided adrenalectomy was performed 10 months after right-sided surgery, and histopathological examination revealed also PPNAD features. The patient has been on $\mathrm{HC}$ and fludrocortisone replacement therapy since then. When she was 23 years old, genetic testing was performed, and a mutation (c.125dupG) in the PRKAR1A gene was found.

$\mathrm{CNC}$ was diagnosed on the basis of three main criteria (PPNAD, myxomas, melanosis of the anterior segment of the eye).

\section{Case report 2}

A 15-year-old male patient has been observed in the Endocrinology Outpatient Department since the age of 13 years due to slow growth rate and excessive weight gain. He was born preterm (36 week of pregnancy) as the fourth child of healthy parents. His psychomotor development was delayed (sitting — nine months, walking - two years). Since his second year of life deteriorating visual acuity has been observed. When he was five years old, atrophy of both optic nerves of unknown aetiology was diagnosed. On admission to the Endocrinology Department CMHI, red striae on his arms and lower abdomen and acne on his face face were found. Pubertal development was at the following Tanner stages: genitals 3 and pubic hair 3 [6]. The testicular volume was $6 \mathrm{ml} / 8 \mathrm{ml}$. Laboratory tests showed (Table I and II): loss 
Table I. Cortisol circadian rhythm at the diagnosis and during re-manifestation of the disease after one-side adrenalectomy [ug/dl] Tabela I. Dobowy rytm kortyzolu w momencie diagnozy i podczas nawrotu choroby po jednostronnej adrenalektomii [ $\mu \mathrm{g} /$ dl]

\begin{tabular}{lcccc}
\hline & $\mathbf{8 . 0 0}$ a.m. & $\mathbf{0 8 . 3 0}$ a.m. & $\mathbf{0 0 . 0 0}$ a.m. & $\mathbf{0 0 : 3 0}$ a.m. \\
\hline At the diagnosis & & & & \\
\hline Patient 1 & 15.2 & 16.2 & 13.7 & 12.6 \\
\hline Patient 2 & 23.7 & 22.6 & 27.3 & 22.8 \\
\hline During re-manifestation & & & & \\
\hline Patient 1 & 8.6 & 7.3 & 7.3 & 8.0 \\
\hline Patient 2 & 12.5 & 13.8 & 9.0 & 14.5 \\
\hline
\end{tabular}

Table II. Basic hormonal investigations at the diagnosis and hormonal values after low-and high-dose dexamethasone (Dx) test (Liddle's test)

Tabela II. Podstawowe badania hormonalne w momencie diagnozy $i$ wartości hormonów po teście $z$ matq $i$ dużq dawkq deksametazonu (Dx) (test Liddle'a)

\begin{tabular}{|c|c|c|c|c|}
\hline & 8.00 a.m. & Reference & $\begin{array}{l}\text { After } 0.5 \mathrm{mg} \text { of Dx every } \\
6 \text { hours for } 2 \text { days }\end{array}$ & $\begin{array}{l}\text { After } 2 \mathrm{mg} \text { of Dx every } \\
6 \text { hours for } 2 \text { days }\end{array}$ \\
\hline \multicolumn{5}{|l|}{ Patient 1} \\
\hline Cortisol [ug/dl] & 15.2 & $5-20$ & 15.4 & 15.9 \\
\hline ACTH [pg/ml] & 4.73 & $10-60$ & 2.0 & $<2.0$ \\
\hline Androstenedione [ng/dl] & 409 & $50-370$ & 409 & 512 \\
\hline DHEAS [ng/ml] & 716 & $350-4300$ & 725 & 917 \\
\hline Testosterone [pg/ml] & 869 & $88.4-964$ & 869 & 618 \\
\hline \multicolumn{5}{|l|}{ Patient 2} \\
\hline Cortisol [ug/dl] & 20.7 & $5-25$ & 28.2 & 26.2 \\
\hline ACTH [pg/ml] & $<10$ & $10-50$ & $<10.0$ & $<10.0$ \\
\hline Androstenedione [ng/dl] & 338 & $60-380$ & 362 & 452 \\
\hline DHEAS [ng/ml] & 892 & $800-5600$ & 970 & - \\
\hline Testosterone [pg/ml] & 443 & $88.4-964$ & - & - \\
\hline
\end{tabular}

ACTH — adrenocorticotropic hormone; DHEA - dehydroepiandrosterone

of a circadian cortisol rhythm, low plasma ACTH level $(<10 \mathrm{pg} / \mathrm{ml})$, increase of plasma cortisol after LDDST and HDDST, increase of 17-hydroxycorticosteroids in urine after LDDST (8\%) and HDDST (36\%). CNC was suspected on the basis of clinical picture and suspicion of heart myxoma in the echocardiogram. CRH stimulation test showed no increase of ACTH and cortisol after stimulation. Echocardiography showed no abnormalities, MRI showed adrenal glands with uneven margins, without thickening. On the basis of densitometry low BMD was diagnosed (total Z-score: -2,7 SD; L2-L4: -4,3 $\mathrm{SD})$. Right-sided laparoscopic adrenalectomy has been performed (with no need of subsequent HC substitutional therapy). After five months acceleration of growth rate $(6 \mathrm{~cm} /$ year), weight loss $(6 \mathrm{~kg})$, and withdrawal of stretch marks and acne were observed. During the following two months weight gain $(4.6 \mathrm{~kg})$ and pale-pink stretch marks appeared again. Laboratory: loss of a circadian cortisol rhythm (Table I). Steroid profile in urine revealed slightly increased cortisol metabolites with marked deficiency of $5 \alpha$-reductase and increased ratio of free cortisol to cortisone. Androgens plasma levels were normal, ACTH plasma level was below the normal range. The patient underwent a left-sided adrenalectomy eight months after removal of the right adrenal gland. The diagnosis of PPNAD was confirmed by histopathological examination of both adrenals (Fig. 2). The patient is on $\mathrm{HC}$ and fludrocortisone replacement therapy. Genetic testing revealed a mutation (c.15dupT) in the PRKAR1A gene.

\section{Discussion}

PPNAD is a histologically benign form of BAH [9], which causes CS that can be clinically evident or subclinical, constant, or cyclic [10]. It is the most frequent presentation of CNC in teens and young adults [11, 12], with the peak of occurrence in the third decade of life 


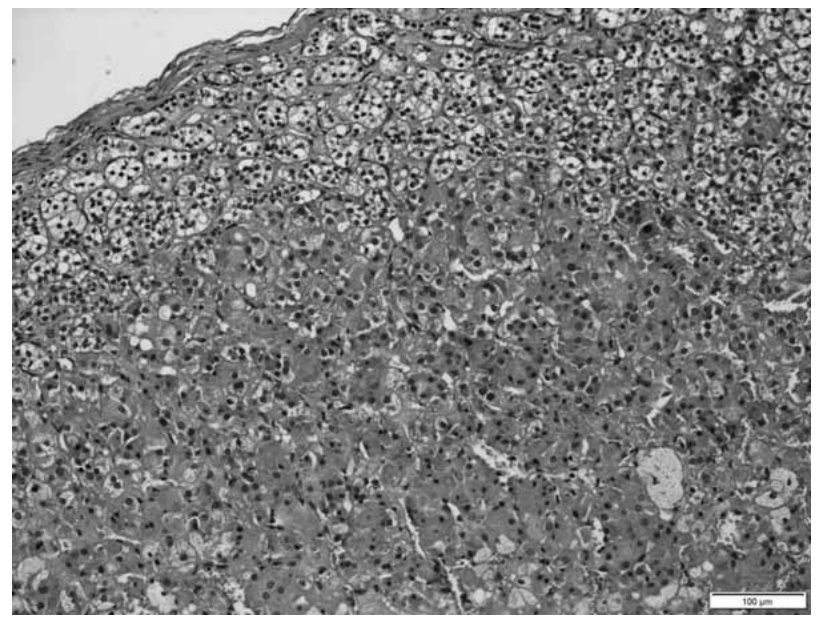

Figure 2. PPNAD, adrenal gland (patient 2). Original magnification $200 \times$, haematoxylin and eosin staining

Rycina 2. PPNAD, nadnercze (pacjent 2). Oryginalne powiększenie $200 \times$, barwienie hematoksylina i eozyna

[13]. Clinical signs of CS are quite similar to those seen in patients presenting with other causes of hypercortisolism [13-15]. The most frequent symptoms of CS are: weight gain, central obesity, and slower growth rate during childhood [16]. PPNAD usually presents at a young age but not in infancy, whereas adrenal hyperplasia due to McCune-Albright syndrome usually presents in the infantile period. Other adrenocortical tumours may present before the age of five years, and they often manifest as precocious puberty [11, 16-18]. Hypogonadism is frequently observed in patients with adrenal lesions that do not secrete androgens [19].

Among 72 children with CS due to PPNAD 29\% presented with short stature [13]. However, growth arrest is not a constant finding in children with PPNAD as emphasised by Groussin et al., and the classical features of CS in patients with PPNAD can be absent in childhood [14]. Güemes et al. in their analysis of 30 paediatric patients with CS showed that a decreased growth rate was observed in $36.6 \%$ of patients [10]. Growth failure was common in pituitary CD patients but not in ACTH-independent CS. The authors explain that while pure cortisol-secreting pituitary CD would inhibit growth (cortisol suppresses GH production [21], combined with a possible pituitary mass effect leading to GH deficiency), adrenal tumours causing CS may cosecrete androgens, and hence stature would be less affected.

According to the case reports from literature, the mean time between diagnosis of endogenous CS and detection of the first component of the disease is about 2-3 years (range between 0.2 to as much as 9 years) [11, 22-24]. The symptoms and signs of CS in PPNAD are insidious, the clinical manifestation may be subtle, and most patients come to medical attention several years after their onset [25-27]. In the presented patients this time was 3 and 3.5 years. In the case of late diagnosis of PPNAD, osteoporosis is common [14]; in both analysed patients low BMD was diagnosed.

In most patients with PPNAD a paradoxical increase of cortisol level after LDDST or HDDST is observed; an increase in urinary free cortisol excretion on the second day of HDDST $>50 \%$ of the basal level usually supports the diagnosis of PPNAD [1]. It is established that dexamethasone paradoxically stimulates cortisol release through a glucocorticoid receptor-mediated effect on PKA catalytic subunits [28]. There was a $36 \%$ increase of serum cortisol after LDDST and $27 \%$ after HDDST in patient 2, and a non-significant increase, instead of a decrease, was observed in patient 1 .

Adrenal glands are most commonly normal or even small in size in adrenal imaging [29, 30]. Indeed, in our patients, the adrenal glands were not enlarged in $\mathrm{CT} / \mathrm{MR}$ imaging.

Treatment recommendations for PPNAD vary. Many authors suggest bilateral adrenalectomy [3, 12, 31, 32]; others think that in some cases clinical and biochemical improvement can be achieved by unilateral adrenalectomy, and excision of the second adrenal gland should be considered when hypercortisolism returns [3, 26, 33]. However, the Endocrine Society clinical practice guidelines from 2015 recommend one-stage surgical resection of bilateral adrenal disorders [34].

Some rare cases have been treated with mitotane or ketoconazole. Campo et al. [35] presented 10-year observation of a 27 -year-old female who did not agree to the surgical method - she was treated with mitotane with sustained regression of CS features without inducing adrenal insufficiency.

In rare patients, in whom clinical CS did not recur after unilateral adrenalectomy, loss of circadian cortisol rhythm can be observed in long-term follow-up, showing that despite apparent clinical cure the disease is indeed bilateral [26].

The reason for bilateral adrenalectomy is also the fact that in the case of unilateral surgery preserved adrenal tissue acts autonomously, which increases the risk of adrenal failure [36-39]. In our patients the need for contralateral adrenalectomy occurred in 6-7 months of follow-up, which supports the opinion of the need of bilateral adrenalectomy.

\section{Carney complex}

CNC was first reported by JA Carney in 1985 [40]. CNC is a multiple neoplasia syndrome featuring endocrine, cardiac, cutaneous, and neural tumours [41]. In patients with CNC tumours of two or more endocrine glands are reported, including PPNAD, somatotropinoma and 
Table III. Diagnostic criteria for Carney complex [41]

Tabela III. Kryteria diagnostyczne dla zespołu Carneya [41]

\section{Clinical criteria}

1. Spotty skin pigmentation with a typical distribution (lips, conjunctiva and inner or outer canthi, vaginal and penile mucosa)

2. Myxoma (cutaneous and mucosal) ${ }^{\mathrm{a}}$

3. Cardiac myxoma ${ }^{a}$

4. Breast myxomatosis ${ }^{\mathrm{a}}$ or fat-suppressed MRI findings suggestive of this diagnosis ${ }^{\mathrm{b}}$

5. PPNAD ${ }^{\mathrm{a}}$ or paradoxical positive response of urinary glucocorticosteroids to dexamethasone administration during Liddle's test ${ }^{c}$

6. Acromegaly due to GH-producing adenoma ${ }^{\mathrm{a}}$

7. LCCSCTa or characteristic calcification on testicular ultrasonography

8. Thyroid carcinoma ${ }^{a}$ or multiple, hypoechoic nodules on thyroid ultrasonography, in a young patient

9. Psammomatous melanotic schwannoma ${ }^{a}$

10. Blue nevus, epithelioid blue nevus (multiple) ${ }^{\mathrm{a}}$

11. Breast ductal adenoma (multiple)

12. Osteochondromyxoma

\section{Additional criteria}

1. Affected first-degree relative

2. Inactivating mutation of the PRKAR1A gene

aWith histological confirmation; 'Based on Courcoutsakis NA et al. 1997 [52]; 'Based on Stratakis CA et al. 1999 [42]

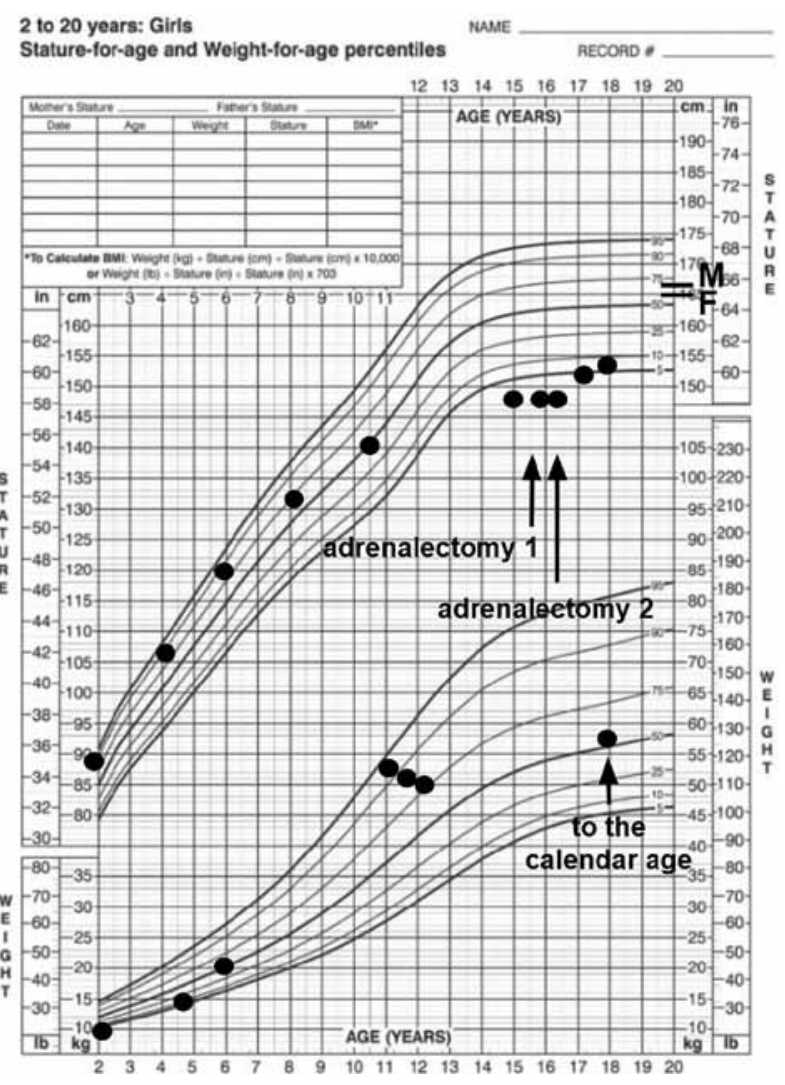

Figure 3. Growth and weight chart of patient 1

Rycina 3. Siatka centylowa wzrostu i masy ciała pacjenta 1

prolactinoma, testicular neoplasms, thyroid adenoma or carcinoma, and ovarian cysts [12, 42-48]. The diagnosis of CNC is based on clinical criteria (Table III) - it requires two main criteria or one main and one additional criterion.

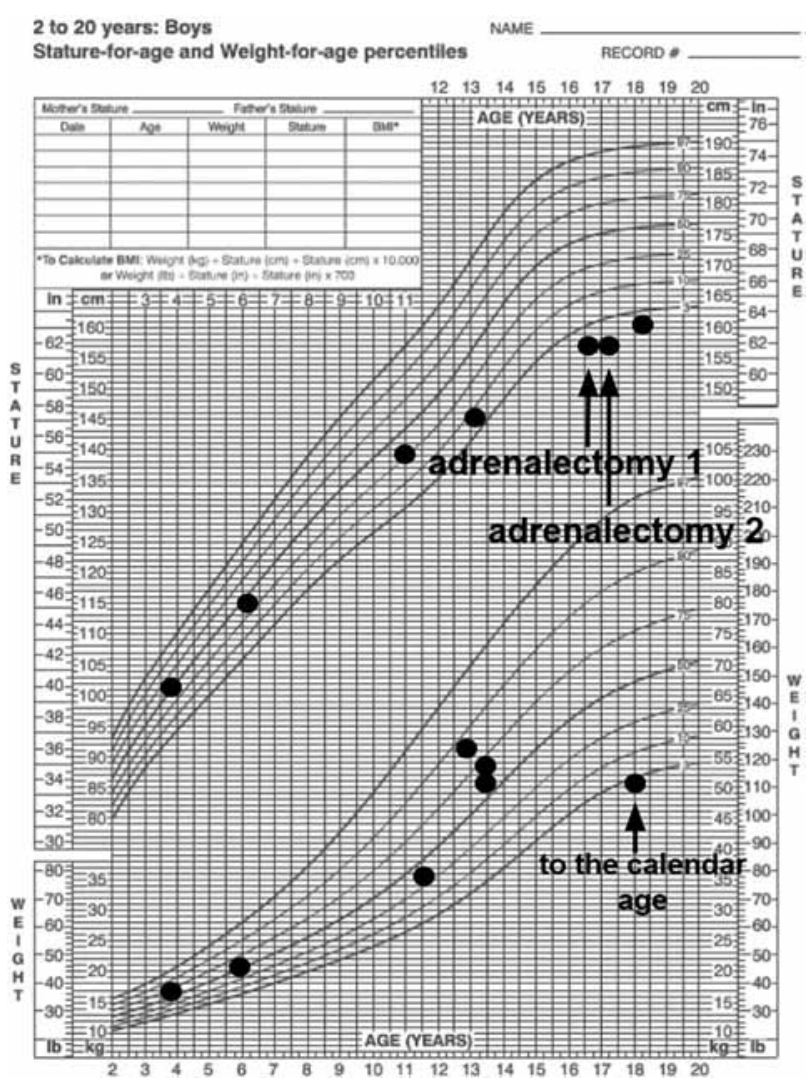

Figure 4. Growth and weight chart of patient 2

Rycina 4. Siatka centylowa wzrostu i masy ciała pacjenta 2

\section{Genetics of Carney complex}

Two distinct loci for $\mathrm{CNC}$ are described: one on chromosome 17q22-24 (CNC1) and the other on chromosome 2 p16 (CNC2) [4, 49]. Inactivating mutations of the PRKAR1A gene responsible for $\mathrm{CNC1}$ are more fre- 
quent [4]. Loss of R1 $\alpha$ function leads to increased cAMP stimulated total kinase activity [5]. The gene responsible for CNC2 is unknown [15]. At this point, there are no clear phenotypic differences between families mapping to one or the other locus.

To our knowledge, it is the first report of such types (c.125dupG and c.15dupT) of detected variants in the PRKAR1A gene. Both c.125dupG and c.15dupT variants are predicted to cause loss of normal protein function either through protein truncation or nonsense mediated mRNA decay. Based on currently available evidence, c.125dupG and c.15 dupT are considered to be candidates for pathogenic PRKAR1A gene variants $[4,50,51]$. However, the possibility they are rare benign variants cannot be excluded.

\section{Conclusions}

Early diagnosis of endogenous hypercortisolism still poses a diagnostic challenge. Novel mutations presented in this article are considered to be pathogenic for PPNAD.

\section{Acknowledgements}

Genetic testing was performed in the National Institute of Health, Bethesda (intramural project Z01-HD008920-01). The patients were recruited under clinical protocol 95CH0059 (which studies patients with Carney complex and related disorders) to the National Institutes of Health (NIH) Clinical Centre. Written, informed consent was obtained from the patients, and the study was approved by the Eunice Kennedy Shriver National Institute of Child Health and Human Development (NICHD) institutional review board. DNA was extracted from peripheral blood leucocytes according to commercially available protocols (QIAGEN, Valencia, CA).

\section{References}

1. Stratakis CA, Boikos SA. Genetics of adrenal tumors associated with Cushing's syndrome: a new classification for bilateral adrenocortical hyperplasias. Nat Clin Pract Endocrinol Metab. 2007; 3(11): 748-757, doi: 10.1038/ncpendmet0648, indexed in Pubmed: 17955016.

2. De Venanzi A, Alencar GA, Bourdeau I, et al Primary bilateral macronodular adrenal hyperplasia. Curr Opin Endocrinol Diabetes Obes. 2014; 21(3): 177-184, doi: 10.1097/MED.0000000000000061, indexed in Pubmed: 24739311.

3. Groussin L, Cazabat L, René-Corail F, et al. Adrenal pathophysiology: lessons from the Carney complex. Horm Res. 2005; 64(3): 132-139, doi: 10.1159/000088586, indexed in Pubmed: 16192737.

4. Kirschner LS, Carney JA, Pack SD, et al. Mutations of the gene encoding the protein kinase A type I-alpha regulatory subunit in patients with the Carney complex. Nat Genet. 2000; 26(1): 89-92, doi: 10.1038/79238, indexed in Pubmed: 10973256.

5. Casey M, Vaughan CJ, He J, et al. Mutations in the protein kinase A R1alpha regulatory subunit cause familial cardiac myxomas and Carney complex. J Clin Invest. 2000; 106(5): R31-R38, doi: 10.1172/JCI10841, indexed in Pubmed: 10974026.

6. Marshall WA, Tanner JM. Variations in the pattern of pubertal changes in boys. Arch Dis Child. 1970; 45(239): 13-23, indexed in Pubmed: 5440182.
7. Baim S, Binkley N, Bilezikian JP, et al. Official Positions of the International Society for Clinical Densitometry and executive summary of the 2007 ISCD Position Development Conference. J Clin Densitom. 2008; 11(1) 75-91, doi: 10.1016/j.jocd.2007.12.007, indexed in Pubmed: 18442754.

8. Lorenc R, Głuszko P, Franek E, et al. Guidelines for the diagnosis and management of osteoporosis in Poland: Update 2017. Endokrynol Pol. 2017; 68(5): 604-609, doi: 10.5603/EP.2017.0062, indexed in Pubmed: 29168548.

9. Bednarczuk T, Bolanowski M, Sworczak K, et al. Adrenal incidentaloma in adults - management recommendations by the Polish Society of Endocrinology. Endokrynol Pol. 2016; 67(2): 234-258, doi: 10.5603/EP.a2016.0039, indexed in Pubmed: 27082051.

10. Kumorowicz-Czoch M, Dolezal-Oltarzewska K, Roztoczynska D, et al. Causes and consequences of abandoning one-stage bilateral adrenalectomy recommended in primary pigmented nodular adrenocortical disease--case presentation. J Pediatr Endocrinol Metab. 2011; 24(7-8): 565-567, indexed in Pubmed: 21932601.

11. Storr HL, Chan LiF, Grossman AB, et al. Paediatric Cushing's syndrome: epidemiology, investigation and therapeutic advances. Trends Endocrinol Metab. 2007; 18(4): 167-174, doi: 10.1016/j.tem.2007.03.005, indexed in Pubmed: 17412607.

12. Sikorska D, Bednarek-Papierska L, Mojs E, et al. Bilateral primary pigmented nodular adrenal disease as a component of Carney syndrome - case report. Endokrynol Pol. 2017; 68(1): 70-72, doi: 10.5603/EP.2017.0008, indexed in Pubmed: 28255981.

13. Carney J, Young W. Primary Pigmented Nodular Adrenocortical Disease and Its Associated Conditions. Endocrinologist. 1992; 2(1): 6-21, doi: 10. 1097/00019616-199201000-00003.

14. Groussin L, Cazabat L, René-Corail F, et al. Mutations of the PRKAR1A gene in Cushing's syndrome due to sporadic primary pigmented nodular adrenocortical disease. J Clin Endocrinol Metab. 2002; 87(9): 4324-4329, doi: 10.1210/jc.2002-020592, indexed in Pubmed: 12213893.

15. Storr HL, Mitchell H, Swords FM, et al. Clinical features, diagnosis, treatment and molecular studies in paediatric Cushing's syndrome due to primary nodular adrenocortical hyperplasia. Clin Endocrinol (Oxf). 2004; 61(5): 553-559, doi: 10.1111/j.1365-2265.2004.02124.x, indexed in Pubmed: 15521956.

16. Stratakis CA. Diagnosis and Clinical Genetics of Cushing Syndrome in Pediatrics. Endocrinol Metab Clin North Am. 2016; 45(2): 311-328, doi: 10.1016/j.ecl.2016.01.006, indexed in Pubmed: 27241967.

17. Dumitrescu CE, Collins MT. McCune-Albright syndrome. Orphanet Rare Dis. 2008; 3: 12, doi: 10.1186/1750-1172-3-12, indexed in Pubmed: 18489744.

18. Kirk JM, Brain CE, Carson DJ, et al. Cushing's syndrome caused by nodular adrenal hyperplasia in children with McCune-Albright syndrome. J Pediatr. 1999; 134(6): 789-792, indexed in Pubmed: 10356155.

19. Alexandraki KI, Kaltsas GA, Isidori AM, et al. Long-term remission and recurrence rates in Cushing's disease: predictive factors in a single-centre study. Eur J Endocrinol. 2013; 168(4): 639-648, doi: 10.1530/EJE-12-0921, indexed in Pubmed: 23371975.

20. Güemes M, Murray PG, Brain CE, et al. Management of Cushing syndrome in children and adolescents: experience of a single tertiary centre. Eur J Pediatr. 2016; 175(7): 967-976, doi: 10.1007/s00431-016-2727-5, indexed in Pubmed: 27169546.

21. van Aken MO, Pereira AM, Frölich M, et al Growth hormone secretion in primary adrenal Cushing's syndrome is disorderly and inversely correlated with body mass index. Am J Physiol Endocrinol Metab. 2005; 288(1): E63-E70, doi: 10.1152/ajpendo.00317.2004, indexed in Pubmed: 15328071.

22. Kelly WF. Psychiatric aspects of Cushing's syndrome. QJM. 1996; 89(7): 543-552, doi: 10.1093/qjmed/89.7.543.

23. Savage M, Chan L, Grossman A, et al. Work-up and management of paediatric Cushing's syndrome. Curr Opin Endocrinol Diabetes Obes. 2008, 15(4): 346-351, doi: 10.1097/med.0b013e328305082f.

24. Malinowska A, Ginalska-Malinowska M, Szmit-Domagalska J, et al. Cykliczny zespół Cushinga u 15-letniej pacjentki. Endokrynol Pediatr. 2009; 2(27): 79-85.

25. Muguruza M, Chrousos G. Periodic Cushing syndrome in a short boy: Usefulness of the ovine corticotropin releasing hormone test. J Pediatr 1989; 115(2): 270-273, doi: 10.1016/s0022-3476(89)80081-2.

26. Sarlis NJ, Chrousos GP, Doppman JL, et al. Primary pigmented nodular adrenocortical disease: reevaluation of a patient with carney complex 27 years after unilateral adrenalectomy. J Clin Endocrinol Metab. 1997; 82(4): 1274-1278, doi: 10.1210/jcem.82.4.3857, indexed in Pubmed: 9100606.

27. Carney JA, Hruska LS, Beauchamp GD, et al. Dominant inheritance of the complex of myxomas, spotty pigmentation, and endocrine overactivity. Mayo Clin Proc. 1986; 61(3): 165-172, indexed in Pubmed: 3945116.

28. Louiset E, Stratakis CA, Perraudin V, et al. The paradoxical increase in cortisol secretion induced by dexamethasone in primary pigmented nodular adrenocortical disease involves a glucocorticoid receptor-mediated effect of dexamethasone on protein kinase A catalytic subunits. J Clin Endocrinol Metab. 2009; 94(7): 2406-2413, doi: 10.1210/jc.2009-0031, indexed in Pubmed: 19383776. 
29. Doppman JL, Travis WD, Nieman L, et al. Cushing syndrome due to primary pigmented nodular adrenocortical disease: findings at CT and MR imaging. Radiology. 1989; 172(2): 415-420, doi: 10.1148/radiology.172.2.2748822, indexed in Pubmed: 2748822.

30. Rockall AG, Babar SA, Sohaib SA, et al. CT and MR imaging of the adrenal glands in ACTH-independent cushing syndrome. Radiographics. 2004 24(2): 435-452, doi: 10.1148/rg.242035092, indexed in Pubmed: 15026592.

31. Bertherat J. Carney complex (CNC). Orphan J Rare Dis. 2006; 1: 21, doi: 10.1186/1750-1172-1-21, indexed in Pubmed: 16756677.

32. Lowe KM, Young WF, Lyssikatos C, et al. Cushing Syndrome in Carney Complex: Clinical, Pathologic, and Molecular Genetic Findings in the 17 Affected Mayo Clinic Patients. Am J Surg Pathol 2017; 41(2): 171-181, doi: 10.1097/PAS.0000000000000748, indexed in Pubmed: 27875378.

33. Zhu Y, Wu YX, Rui W, et al. Primary pigmented nodular adrenocortical disease: report of 5 cases. Chin Med J. 2006; 119(9): 782-785, indexed in Pubmed: 16701022.

34. Nieman LK, Biller BMK, Findling JW, et al. Endocrine Society. Treatment of Cushing's Syndrome: An Endocrine Society Clinical Practice Guideline. J Clin Endocrinol Metab. 2015; 100(8): 2807-2831, doi: 10.1210/jc.2015-1818, indexed in Pubmed: 26222757.

35. Campo MR, Lamacchia O, Farese A, et al. Mitotane and Carney Complex ten years follow-up of a low-dose mitotane regimen inducing a sustained correction of hypercortisolism. Hormones (Athens). 2015; 14(2): 300-304, doi: 10.14310/horm.2002.1514, indexed in Pubmed: 25402388.

36. Kumorowicz-Kopiec M, Starzyk J, Doleżal-Ołtarzewska K, et al. ACTH-niezależna guzkowa choroba nadnerczy jako przyczyna endogennego zespołu Cushinga. Endokrynol Pediatr. 2006; 17(4): 55-62, doi: 10.18544/EP-01.05.04.0055.

37. Storr HL, Chan LiF, Grossman AB, et al. Paediatric Cushing's syndrome: epidemiology, investigation and therapeutic advances. Trends Endocrinol Metab. 2007; 18(4): 167-174, doi: 10.1016/j.tem.2007.03.005, indexed in Pubmed: 17412607.

38. Powell AC, Stratakis CA, Patronas NJ, et al. Operative management of Cushing syndrome secondary to micronodular adrenal hyperplasia. Surgery. 2008; 143(6): 750-758, doi: 10.1016/j.surg.2008.03.022, indexed in Pubmed: 18549891.

39. Kumorowicz-Czoch M, Dolezal-Oltarzewska K, Roztoczynska D, et al Causes and consequences of abandoning one-stage bilateral adrenalectomy recommended in primary pigmented nodular adrenocortical disease--case presentation. J Pediatr Endocrinol Metab. 2011; 24(7-8): 565-567, indexed in Pubmed: 21932601.

40. Carney JA, Hruska LS, Beauchamp GD, et al. The complex of myxomas, spotty pigmentation, and endocrine overactivity. Medicine (Baltimore). 1985; 64(4): 270-283, indexed in Pubmed: 4010501.

41. Stratakis CA, Kirschner LS, Carney JA. Clinical and molecular features of the Carney complex: diagnostic criteria and recommendations for patient evaluation. J Clin Endocrinol Metab. 2001; 86(9): 4041-4046, doi: 10.1210/jcem.86.9.7903, indexed in Pubmed: 11549623.

42. Stratakis CA, Sarlis N, Kirschner LS, et al. Paradoxical response to dexamethasone in the diagnosis of primary pigmented nodular adrenocortical disease. Ann Intern Med. 1999; 131(8): 585-591, indexed in Pubmed: 10523219.

43. Watson JC, Stratakis CA, Bryant-Greenwood PK, et al. Neurosurgical implications of Carney complex. J Neurosurg. 2000; 92(3): 413-418, doi: 10.3171/jns.2000.92.3.0413, indexed in Pubmed: 10701527.

44. Raff SB, Carney JA, Krugman D, et al. Prolactin secretion abnormalities in patients with the "syndrome of spotty skin pigmentation, myxomas, endocrine overactivity and schwannomas" (Carney complex). J Pediatr Endocrinol Metab. 2000; 13(4): 373-379, indexed in Pubmed: 10776991.

45. Pack SD, Kirschner LS, Pak E, et al. Genetic and histologic studies of somatomammotropic pituitary tumors in patients with the "complex of spotty skin pigmentation, myxomas, endocrine overactivity and schwannomas" (Carney complex). J Clin Endocrinol Metab. 2000; 85(10): 3860-3865, doi: 10.1210/jcem.85.10.6875, indexed in Pubmed: 11061550

46. Courcoutsakis N, Patronas N, Filie AC, et al. Thyroid gland abnormalities in patients with the syndrome of spotty skin pigmentation, myxomas, endocrine overactivity, and schwannomas (Carney complex). J Clin Endocrinol Metab. 1997; 82(7): 2037-2043, doi: 10.1210/jcem.82.7.4079, indexed in Pubmed: 9215269.

47. Premkumar A, Stratakis CA, Shawker TH, et al. Testicular ultrasound in Carney complex: report of three cases. J Clin Ultrasound. 1997; 25(4): 211-214, indexed in Pubmed: 9142622.

48. Stratakis CA, Papageorgiou T, Premkumar A, et al. Ovarian lesions in Carney complex: clinical genetics and possible predisposition to malignancy. J Clin Endocrinol Metab. 2000; 85(11): 4359-4366, doi: 10.1210/jcem.85.11.6921, indexed in Pubmed: 11095480.

49. Stratakis CA, Carney JA, Lin JP, et al. Carney complex, a familial multiple neoplasia and lentiginosis syndrome. Analysis of 11 kindreds and linkage to the short arm of chromosome 2. J Clin Invest. 1996; 97(3): 699-705, doi: 10.1172/JCI118467, indexed in Pubmed: 8609225.

50. Horvath A, Bertherat J, Groussin L, et al. Mutations and polymorphism in the gene encoding regulatory subunit type 1-alpha of protein $\mathrm{ki}$ nase A (PRKAR1A): an update. Hum Mutat. 2010; 31(4): 369-379, doi 10.1002/humu.21178, indexed in Pubmed: 20358582.

51. Carney JA, Libé R, Bertherat J, et al. Primary pigmented nodular adrenocortical disease: the original 4 cases revisited after 30 years for follow-up, new investigations, and molecular genetic findings. Am J Surg Pathol. 2014; 38(9): 1266-1273, doi: 10.1097/PAS.0000000000000220, indexed in Pubmed: 24805858 .

52. Courcoutsakis NA, Chow CK, Shawker TH, et al. Syndrome of spotty skin pigmentation, myxomas, endocrine overactivity, and schwannomas (Carney complex): breast imaging findings. Radiology. 1997; 205(1): 221-227, doi: 10.1148/radiology.205.1.9314989, indexed in Pubmed: 9314989. 